\title{
THE WORK OF THE NEW ECONOMY: Consumers, Brands, and Value Creation
}

\author{
ROBERT J. FOSTER \\ University of Rochester
}

\section{QUALITATIVE RESEARCH AND KNOWING CONSUMERS}

Several years ago, as part of an internship with the New York office of a transnational advertising agency, I was dispatched to do laundry. My destination: Astoria, Queens, where I visited the home of Lois, a white, married, 40 something, college-educated, middle-income mother of two school-age girls. Lois had been previously identified by the agency as a brand loyalist - someone whose last six purchases of laundry detergent were of a brand that I shall call "Wave."

During a previous one-on-one interview at the agency, a Wave account planner asked Lois to make two collages by cutting and pasting pictures from dozens of glossy magazines spread out across a conference table. One collage expressed how Lois felt when her dirty laundry had piled up or when a favorite piece of clothing had become irremediably stained; the other collage expressed how Lois felt after she had finished washing and drying her clean laundry. My field trip, during which Lois and I did a load of whites together, was intended to follow up the office visit both by comparing word and deed and by gleaning bits of the laundry process that had not been gathered in the interview. The goal of my qualitative research was, in effect, to ascertain the unspoken emotional and symbolic implications of doing laundry by determining the social contexts and relations that Lois constructed through her use of Wave detergent.

CULTURAL ANTHROPOLOGY, Vol. 22, Issue 4, pp. 707-731. ISSN 0886-7356, online ISSN 1548-1360. (C) 2007 by the American Anthropological Association. All rights reserved. Please direct all requests for permission to photocopy or reproduce article content through the University of California Press's Rights and Permissions website, http: / /www.ucpressjournals.com / reprintInfo.asp. DOI: 10.1525/can.2007.22.4.707. 
What exactly was at stake for this advertising agency in knowing Lois's laundry habits? The agency's explicit concern with the affective dimensions of the personproduct relationship has now become a central preoccupation of brand managers, especially within the fast-moving consumer goods industry (see O'Shauaghnessy and O'Shaughnessy 2003). This preoccupation is succinctly formulated in the idea of Lovemarks. Lovemarks, according to Kevin Roberts, CEO Worldwide of Saatchi \& Saatchi Advertising, are what represent the next step in the evolution of brands. Lovemarks are brands that are not simply respected and trusted, but loved. Lovemarks possess a "special emotional resonance" (Roberts 2004:74; see also Lovemarks.com n.d.). They signal an emotional connection and attachment to a brand that goes beyond reason - and for which a premium price can be charged. At stake, then, in Lois's laundry habits was the particular love for her family that she performed in washing their clothes with Wave. At stake was the possibility of tapping into this love and rendering it a quality of a particular laundry detergent — of representing the Wave brand as the sign and instrument of the close kin relationships made and remade in the act of doing laundry.

Kevin Roberts's discourse on the relationships between persons and products and thus the relationships among consumers, companies, and brands is not merely the breathless hyperbole of a high-octane salesman. Over the last few years, one could hear similar talk in the sober corporate reports of heavily branded consumer goods. For example, The Coca-Cola Company 2002 annual report, pertinently entitled "Creating New Value," asserts "The creation of new value begins with a commitment to innovation - the kind of insight, creativity and determination that brings to life new ideas, new products and new consumer experiences." Value creation so defined hinges on managing relations between consumers and the brand. Douglas Daft, then-CEO of the company, explained to "shareowners" that: "Responsibility for the world's most beloved and valuable brand requires extreme care in how, when and why we extend it. We don't risk consumer loyalty to the brand or seek an artificial bump in volume by spinning out product after product to chase the latest fad. But we do ask ourselves continually how we can bring more people to Coca-Cola."

Not only must brand extensions in the form of Diet Coke, Vanilla Coke, and so forth be made judiciously but the brand must also be associated with people's emotional experiences; or as the report proclaims, "Value is: connecting with the world's passions." On a global scale, this requirement motivates the company's sponsorship of both the Olympic Games and soccer's International Federation of Football Association (FIFA) World Cup tournament - "the world's only truly global 
sporting events." It also underwrites the efforts of The Coca-Cola Company to reproduce demand for its beverages; or as the report proclaims, "Value is: refreshing a new generation of consumers." From its television sponsorship of American Idol to its nightclub marketing in Europe, the company pursues unconventional ways to forge "deep connections" with teens and young adults, ways "to speak to them on their terms - and on their turf." Underlying these various initiatives is a single goal: "to create experiences for young consumers that are rewarding, unexpected and true to The Coca-Cola brand.” Like Kevin Roberts, then, Daft clearly identifies the dynamic relationships between consumers and companies - relationships that are mediated by brands - as integral to the process of creating (new) value. Value creation so defined thus involves both providing products that meet the needs of consumers and providing shareholders with attractive returns on their investments.

My goal in this article is to apprehend claims about person-product relationships circulating in the world of business by means of cognate ideas born of a merger between science studies (see Latour 2005a) and economic sociology (see Granovetter and Swedberg 2001). These ideas presuppose the embeddedness of economic action in shifting networks or assemblages of people and things (human and nonhuman actors), and they call attention to the agency distributed within such networks. I refer specifically to the work of Michel Callon and his colleagues and to their notion of "the economy of qualities" (Callon et al. 2002). I pose two sets of related questions. First, can we translate the marketing claim that relationships between consumers and corporate brands define a locus of value creation into the terms of Marx's theory of value; and how might this translation revise not only the marketing claim but also Marx's understanding of surplus value creation?

For Karl Marx, the labor process under capitalism produces a commodity or use-value that has value in exchange — an exchange value that is, moreover, greater than the sum of the values of the commodities consumed in its production. This surplus value creation occurs outside the sphere of circulation, in the hidden abode of production, in which that peculiar commodity, labor power, is consumed. Such "productive consumption," according to Marx, differs from "individual consumption"; the latter "uses up products, as means of subsistence for the living individual" (1967:183). For Marx, "the product, therefore of individual consumption, is the consumer himself; the result of productive consumption, is a product distinct from the individual" (1967:183). Is there a way to understand business claims about person-product relationships by locating surplus value creation in practices of what Marx called "individual consumption," that is, in the production of consumers themselves or in the consumption of commodities other than labor power? Is there a 
way, in other words, to recover the place of use-value - the useful qualities of products - in the creation and extraction of surplus value?

Second, can we translate the claim that value creation hinges on a dynamic relationship between corporations and consumers into terms of a theory of participatory democracy? That is, what sort of political potential might inhere in this relationship? In particular, how might this relationship endow consumers with agency not only in value creation but also, to borrow Bruno Latour's (2005b) phrase, in making things public? I suggest that the sociotechnical networks that form around the movement of commodities variously enable consumers to address matters of concern and perforce to constitute themselves as publics - as affiliations performed by attempts to hear themselves and make themselves heard on a particular subject (cf. Warner 2002)? I here follow some recent attempts to recover from Walter Lippman (1925) and John Dewey (1946) the notion of a public as a group of people that emerges with reference to a matter of concern, that is, a matter identified and evinced as negatively affecting people uninvolved in producing the matter in the first place (see Callon 2005; Latour 2005b; Marres 2005). "For," as Dewey put it, "the essence of the consequences which call a public into being is the fact that they expand beyond those directly engaged in producing them" (1946:27; see Marres 2005:214).

Such publics emerge, most notably, around "corporate externalities," the costs of a corporation's doing business passed on to other people by its managers and shareholders; and these publics emerge on an expanded spatial scale as the commodity networks connecting diverse economic actors extend across vast distances. Thus, for example, "fair trade" publics have emerged in the United States and Europe around concerns over the conditions under which farmers grow and sell tropical food commodities - coffee, bananas, and cocoa - in Peru, Jamaica, and Ghana. How, then, might such publics shape or disrupt processes of value creation in the economy of qualities - especially when the value of brands is understood by their owners to depend not merely on the trust of consumers but on nothing less than the active love of consumers?

I approach the issue of value creation through a brief explication of Callon's notion of "the economy of qualities" and its resonance with the claims of current business rhetoric, and I subsequently take up the question of surplus value that neither Callon nor the business literature engages. I address the question of commodity networks and consumer agency through a discussion of two types of images drawn from my research into the sociotechnical lives of an iconic global commodity: branded soft drinks. (Soft drinks, like laundry detergents, are consumer items that rely heavily on brand identity to distinguish themselves from their competitors.) 


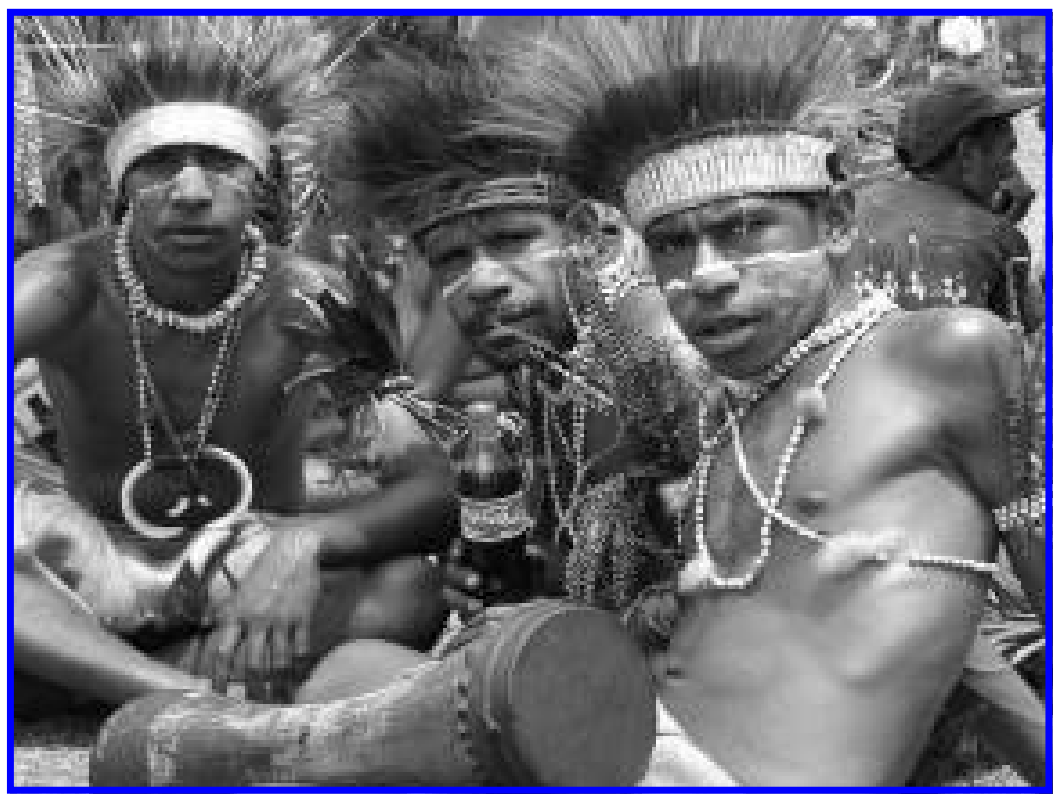

FIGURE 1. Dancers pose at the 2006 Goroka Show, an annual cultural festival held in the Highlands of Papua New Guinea. (Photograph by Jan Hoeksema.)

The first type of image engages a common ironic and playful qualification of soft drinks as modern complements to traditional ways of life. This example was taken at a popular cultural festival in the highlands of Papua New Guinea (see Figure 1). The second type of image suggests a serious and critical qualification of soft drinks as signs of corporate globalization, as threats to all ways of life. This particular example was taken during a student protest against The Coca-Cola Company at Yale University (see Figure 2). Both types of images raise questions about the limits and possibilities of consumer agency in the economy of qualities for assembling a public around matters of concern.

\section{THE ECONOMY OF QUALITIES}

The significance of the deep emotional connections that marketing executives so purposively seek can be appreciated as a function of the way that Callon defines a product as mutable or never quite finished:

A product . . . is an economic good seen from the point of view of its production, circulation and consumption. The concept (producere: to bring forward) shows that it consists of a sequence of actions, a series of operations that transform it, move it and cause it to change hands, to cross a series of metamorphoses that end up putting it into a form judged useful by an economic 


$$
\square
$$


agent who pays for it. During these transformations its characteristics change. [Callon et al. 2002:197]

In other words, the product is a variable, a contingent outcome of negotiationseven conflict - around the qualification of goods (see Ponte and Gibbon 2005). This process of "evaluation," of qualifying and requalifying products, unfolds at all moments in the biography or career of a product - design, manufacture, marketing, use, recycling, and so forth. But at certain moments, the qualities of a product are stabilized; the product becomes a "good," its list of qualities closed at least temporarily.

Callon echoes contemporary marketing rhetoric in asserting that consumers are just as active as any other economic agent-designers or advertisers, for example - in qualifying products: "There is no reason to believe that agents on the supply side are capable of imposing on consumers both their perception of qualities and the way they grade those qualities" (Callon et al. 2002:201). Accordingly, the product, understood as a sequence of transformations or as a process of qualification and requalification, links consumers into the different networks coordinating all the agents involved in production, design, and so forth - agents who most likely never encounter each other face to face or even know of each other's existence in precise terms: "The product singles out the agents and binds them together and, reciprocally, it is the agents that, by adjustment, iteration and transformation, define its characteristics" (Callon et al. 2002:198). Hence, the product implies a dynamic "economy of qualities," an economy in which tradable goods in the market are defined by the characteristics attributed to them in successive qualifications and requalifications, including those enacted by consumers.

I should be careful here not to imply that the economy of qualities refers to some version of a "new economy" thought to be less material than the "old economy" concerned more, for example, with signs and meanings than with physical or material objects, or more with services than with goods. Instead, I emphasize that the notion of an economy of qualities helps to apprehend a change in the conditions of stability and instability of products. As the sociologist Don Slater insists: "it is not that commercial objects have become more like signs, but that things in general have become sites of intense social and economic contestation such that they have become increasingly provisional and incipiently unstable as materialities" (2002:96). That is, instability is always a property of products and, thus, always a potential resource to be mobilized by the various actors (including nonhuman actors) networked by products (Slater 2002:98). In this sense, the economy of qualities describes 
nothing historically new or exclusive to market transactions; it is a concept that, for example, makes visible aspects of economic activity in "gift societies" as well as in "commodity societies." Indeed, Callon's observation about the mutual definition of agents and products directly recalls Nancy Munn's trenchant remarks about kula shells: "Although men appear to be the agents in defining shell value, in fact, without shells, men cannot define their own value; in this respect, shells and men are reciprocally agents of each other's value definition" (1983:283). However, as Slater notes, the extent to which specific practices (marketing, brand consultancy, and design) reflexively alter the qualities of products to secure competitive advantage has now brought the dynamics of stabilization and destabilization into the very center of capitalist markets for consumer goods. What do these dynamics look like to Callon?

For Callon (2001), one symptom of the current economy of qualities is what he calls "voicy consumers." The voicy consumer is an active consumer-but not merely the now-familiar figure who far from being a passive dupe is, in certain instances, an efficacious agent of subversion and resistance. Callon's voicy consumers are as much the precondition of the economy of qualities as they are its undoing. That is, designers, manufacturers, and marketers welcome and invite voicy consumers to involve themselves in the qualification of products - to criticize, to share their feelings, and to interact with other consumers. In its ideal form, then, the economy of qualities entails a fit between qualifications on the supply side and qualifications on the demand side - a fit that needs constant monitoring and adjustment, but nonetheless a more or less stable fit. Such stable fits allow consumers, much like Marx's figure of homo faber, to contemplate themselves in a product that reflects their own singular qualities. At least for a while.

Voicy consumers, however, are also potential sources of destabilization, sources for the production of new identities and new groups that exceed the capacity of any firm to anticipate and guide the movements and transformations of a product. The result is a tension integral to the economy of qualities: "In the economy of qualities consumers are thus a constant source of overflowing. And it would be counter-productive to simply suppress these overflowings, because in order to function, markets of the economy of qualities need them" (Callon 2001; see Callon 1998). Consumer overflowings, then, are sources of innovation and competitive advantage for a firm as well as sources of uncertainty and challenges to expertise and authority.

The tension that Callon diagnoses in contemporary economic processes ap714 pears as a practical challenge in contemporary business literature. The threat of 
the voicy consumer- "better informed, more critical, less loyal, and harder to read" (Roberts 2004:35) - haunts this literature. How to reckon with this tough character? The consensus seems to be, as the notion of Lovemarks demonstrates, by attempting to incorporate and manage the requalification or destabilization of products as part of normal business. Even if this sort of management has been going on since Josiah Wedgwood invented product placement in the 18th century, my point again is that such reflexive intervention on the part of firms into the processes whereby products are qualified and materialized has become central to commercial practice (see Slater 2002). Methodologically, such management exercises require microsociology and detailed ethnography_including field trips to Queens to do a load of whites - methods that market researchers share with proponents of science and technology studies. Theoretically, the reflexive management of qualifications requires of businesses new ways of thinking about value creation, to which I now turn.

\section{VALUE (CO-)CREATION}

Callon's notion of the economy of qualities complements the claims of contemporary business literature that value creation is a process of cooperation between producers and consumers. The business literature, as already indicated, represents this process as essentially cooperative, a long-term relationship of intimacy and respect, an enduring yet evolving love affair between equal partners. C. K. Prahalad and Venkat Ramaswamy, both professors of business, have recently theorized how the "interaction between the firm and the consumer is becoming the locus of value creation" (2004a:5; see also 2004b). More precisely, this interaction is the locus of "cocreating" value. That is, consumers now no longer merely purchase offerings autonomously created by the firm, but instead engage in personalized interactions with the firm with the aim of cocreating products and services that realize desired outcomes. This engagement has been identified as a trend, dubbed "CustomerMade" and defined as "The phenomenon of corporations creating goods, services and experiences in close cooperation with experienced and creative consumers, tapping into their intellectual capital, and in exchange giving them a direct say in (and rewarding them for) what actually gets produced, manufactured, developed, designed, serviced, or processed" (Trendwatching.com n.d.).

More radically, Prahalad and Ramaswamy see the roles of production and consumption, producer and consumer converging in the cocreation of experiences that deliver "unique" value to consumers. That is, these experiences and the interactions that facilitate them necessarily vary from individual consumer to individual 
consumer. They vary because firms can never fully control or manage how individual consumers will go about the cocreation of their experiences. Firms that pay attention to such variable cocreation experiences, Prahalad and Ramaswamy argue, enable consumers to cocreate value that these same consumers are "by design, 'willing to pay for' " (2004a:13). Such firms therefore put themselves in a position to defend against the "commoditization" of their products and services. By commoditization, Prahalad and Ramaswamy mean a process by which competition renders price the only quality relevant to consumers; that is, commoditization results in consumers seeking the lowest price possible for products regarded as generic and interchangeable.

To be fair, Prahalad and Ramaswamy also recognize that firms and consumers are not only cooperators but also competitors. (Indeed, one of Prahalad and Ramaswamy's [2000] earlier articles was bluntly entitled "Co-Opting Consumer Competence.") Firms and consumers compete in the extraction of value from cocreation experiences; firms and consumers coextract as well as cocreate value This agonistic aspect of the joint labor in value creation is slightly more pronounced in Callon's representation of the economy of qualities. Callon talks of "conflict and negotiation around the qualification of goods" (Callon et al. 2002:197). He locates the qualification of goods at "the heart of economic competition and the organization of markets," a process that "different economic agents can manipulate to suit their strategic goals" (Callon et al. 2002:200). And these economic agents include not only competing firms but also consumers whose attachment to particular goods is always contingent, a function of qualifications or evaluations that are never final. The danger of inattention to cocreation against which Prahalad and Ramaswamy warn thus signals a basic paradox that Callon's current economy of qualities presents to firms:

In the economy of qualities it is preferable for the service provider to cooperate with the consumer and therefore to deal with a calculating consumer, at least on a regular basis without long intervals in-between. This is possible only by limiting the periods of routine attachment and by constantly calling into question the singularization of products proposed in order to launch new negotiations and adjustments of their (re)qualification. [Callon et al. 2002:211-212]

In other words, because of the constant need for a firm to stay in touch with the consumer's qualifications, the reflexive destabilization of products moves to the center of marketing practice. 
Both versions of value creation-Callon's competitive game and Prahalad and Ramaswamy's cooperative interaction - sidestep Marx's question of surplus value. What are the implications of "cooperation" or joint labor in the process of value creation for our understanding of the appropriation of surplus value and the generation of profits? In what ways, in particular, is the labor of the active or voicy consumer a source of surplus value in the economy of qualities? These questions require further consideration of the nature of use-value.

\section{BRAND VALUE AND SURPLUS VALUE}

Consider brands. The economic value of brands is now measured by such devices as the annual Interbrand-BusinessWeek survey, according to which the brand Coca-Cola was worth $\$ 67.5$ billion in 2005, about 64 percent of the company's market capitalization (Interbrand n.d.). No doubt brands are built through the various strategies deployed by brand owners with regard to marketing; but brands held as corporate assets are also produced by consumers, through the everyday practices in which consumers use branded goods to create social relations and shared meanings and affect. This sort of consumer productivity unfolds beyond the reach of the firm; it is an external productivity that firms increasingly seek to tap if not appropriate. Brands thus translate the particular use-values created by the labor of consumers (through and outside interactions with firms) into a more general and comparable value form.

Kevin Roberts recognizes this translation in his claim that "Brands aspiring to be Lovemarks must develop intuitive listening skills and ways to harvest stories of their consumer experiences" (2004:90). Recall how Lois's orientation and devotion to her family was performed in the laundry process. There was only one hamper in the tidy three-bedroom two-level row house. It was a white wicker basket located next to the washing machine and dryer, which were located on the ground floor in a converted closet space adjacent to the family room. Each family member was responsible for depositing his or her dirty clothes in this hamper. Similarly, family members would deposit dirty towels in the hamper after showering in the house's only bathroom, which was also located on the ground floor. Lois was the sole person responsible for sorting through the hamper, separating the clothes into whites and colors, and washing and drying the clothes. Occasionally her daughters would help Lois sort and fold the dried clothes and bring them to their rooms; Lois's husband, however, never participated in the laundry process and she put his clothes away for him. She was the person responsible for accomplishing the orderly and regular transformation of the dirty clothes collected in the family hamper and supervising 
the return of clean clothes to each separate family member's closet or dresser. Lois's laundry routine thus constructed a set of kin relations that defined her as the person responsible for caring for the household's clothing. These kin relations, and the force of moral personhood implicated therein, stretched beyond the bounds of Lois's own household. It is hardly irrelevant - and completely consistent with the agency's profile of brand loyalists - that Lois began using Wave on the recommendation of her mother, who also used the brand.

Stories such as Lois's alert brand owners to the ways in which consumers use products in myriad personal projects of self-fabrication and, especially, infuse certain products with emotion; for, as Kevin Roberts notes, "best of all, emotion is an unlimited resource" (2004:43). Getting in touch or emotionally connecting with consumers is thus a precondition for translating consumption work - the use of products - into surplus value. (By consumption work, I refer to the social practices by which persons transform products into artifacts "invested with particular inseparable connotations" [Miller 1987:190]). This translation involves treating the production of consumers themselves, to recall Marx's terms - the production of their subjectivity - as a source of value creation from which surplus value can be extracted. How is this translation accomplished?

I submit that consumption is a form of labor open to exploitation analogous to wage labor (see Foster 2005). Adam Arvidsson (2005:237) similarly suggests that consumers, active and creative, produce an "ethical surplus" - "a social relation, a shared meaning, an emotional involvement that was not there before" - in their use of branded goods. That is, consumers use goods to produce a "common"-a communicative context within which goods can acquire use-values. Brand management, then, is all about guiding and anticipating this productive process without suppressing the creativity and autonomy of consumers. For Arvidsson, brand management exploits consumers in two ways: quantitatively, by absorbing the time consumers put into creating a common, and qualitatively by establishing the production of a common through communicative interaction on the premise of brands as necessary means of production.

Put otherwise, brands represent the appropriation of the appropriations of branded goods by consumers. This way of putting things emphasizes the "marks" in Lovemarks, for despite rhetorical claims to the contrary, brands that qualify as Lovemarks are the legally protected intellectual property of brand owners. Accordingly, the premium price that consumers pay for brands represents a charge levied for access to the meanings, social relations, and affect that consumers themselves have produced (see Coombe 1998). Jones Soda Company (n.d.), a 
Seattle based soft-drink firm and a clear example of the phenomenon of "CustomerMade," regularly changes the labels on its glass bottles. These labels feature black and white photographs - of landscapes, children, or cars - submitted by consumers of Jones Soda. According to a New York Times business report, "To Charge Up Customers, Put Customers in Charge" (Taylor 2006), Jones customers can order for $\$ 34.95$ a 12 -pack that features their own photographs"a form of Internet-enabled personalization that is the company's highest-margin business."

Given that the creativity and agency of consumers is always productive of new meanings, relations and affect, brands thus function for their owners as stable platforms for the perpetual destabilization or requalification of products. Herein perhaps lies the significance of the distinction between goods and services in defining a "new economy": goods that consumers once owned are now effectively services that consumers lease on a continuing basis. It is as if the new economy is a version of the (really old) kula economy, in which what Malinowski called "cumulative possession" is the norm: shell valuables must always, sooner or later, be passed on to one's partners. That is, what the new economy reflects is not the dematerialization of things into events, but a shift from the permanent transfer of ownership of things to the ongoing rental of things. In buying branded goods, consumers pay again and again to recover the outcomes and means of their own productivity and subjectivity.

Brand management, then, is ideally a solution to the paradoxical problem identified by Callon, on the one hand, and by business writers like Prahalad and Ramaswamy, on the other hand. Voicy consumers need to be actively engaged, their creativity and innovation encouraged as part of the never-ending quest to requalify products for purposes of competitive advantage. At the same time, this agency and innovation needs to be anticipated and guided, contained within the parameters of a brand's identity. Consumer overflowings are welcome to the extent that they develop the brand in certain directions, but unwelcome to the extent that they exceed the frames of permissible or manageable use. What sort of possibilities for a politics of value (creation) does this delicate task of managing the economy of qualities open up and shut down? For if the reflexive destabilization of products preoccupies marketing executives, then it is fair to say that it also preoccupies many consumers. What sort of possibilities for alternative forms of joint action-for making new publics - emerge as the commodity networks enrolling consumers lengthen to include "actors and interests operating at different spatial scales" (Slater 2002:106)? 


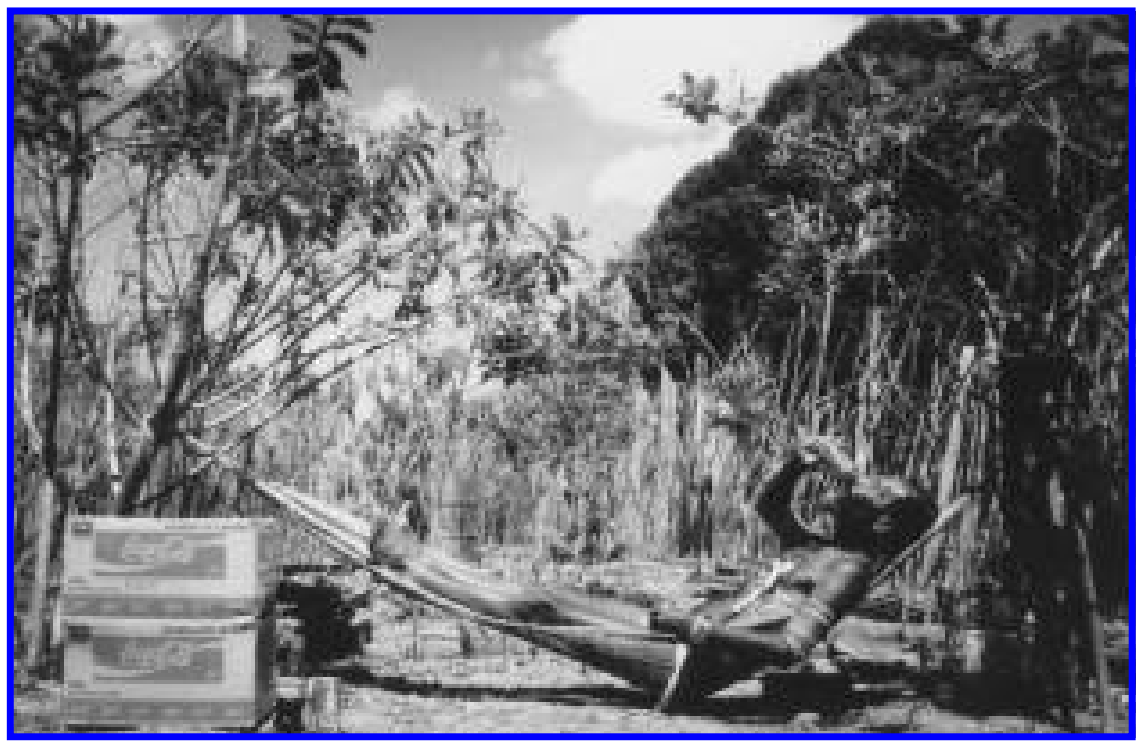

FIGURE 3. Alphonse Hega's second entry for the 1998 Coca-Cola PNG national calendar competition. (Photograph by Alphonse Hega [see Hirsch 2004].)

\section{MAKING THINGS PUBLIC IN THE ECONOMY OF QUALITIES}

These questions can be taken up through two separate cases of the dynamics of (de)stabilizing products. Although quite different, both cases hinge on the evaluation of commodities stamped with the same iconic global brand.

Case One. In 1997, the Coca-Cola bottler in Papua New Guinea (PNG) sponsored a competition in which people were invited to send photographs for inclusion in the annual company calendar. Contestants were advised to take "everyday photos" of people drinking and enjoying Coca-Cola (Hirsch 2004, n. 5). Figures 3 and 4 are photographs taken and submitted by Alphonse Hega; Figure 4 was one of the 12 winners. Hega told anthropologist Eric Hirsch, whose account I draw on here, that the photos were part of a more general strategy to represent the people in Hega's home area in a positive manner and to record their "culture" (Hega's term). The people in Hega's home area, the mountainous Goilala District, have acquired a reputation for criminal activity in nearby urban Port Moresby. Goilala people are also acutely aware of their exclusion from the economic development that Port Moresby symbolizes to them. In this regard, Hega's photographs extended his previous involvement in Christian evangelism and youth education as vehicles for changing the "the bad name of the Goilala" and for asserting belonging in a larger translocal community (Hirsch 2004:22; see also Hirsch 1994, 1995). 


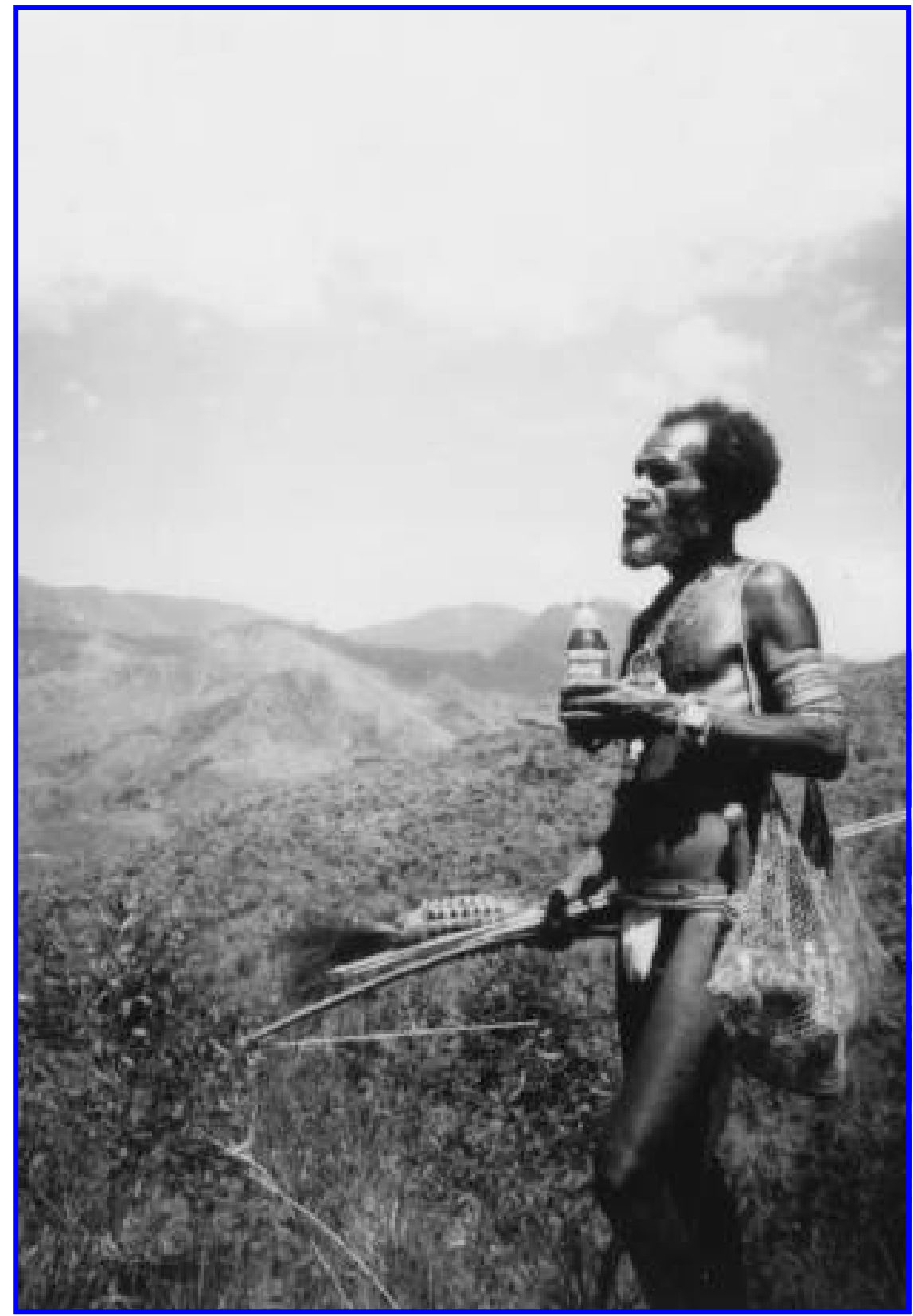

FIGURE 4. Alphonse Hega's winning entry for the 1998 Coca-Cola PNG national calendar competition. (Photograph by Alphonse Hega [see Hirsch 2004].) 
Hega clearly regarded the calendar competition as an opportunity to requalify Goilala "culture"; his horizon encompassed a national field of diverse yet comparable entities or "other cultures." But Hega was also mindful that the Coca-Cola bottling company regarded the competition as a means for qualifying its flagship product. He therefore chose, Hirsch tells us, a "familiar and frequently used motif in order to create the appropriate effect on the judges: the juxtaposition of 'traditional' and 'modern' " (2004:28). In so doing, Hega produced a version of an image with which many Papua New Guineans are long familiar from commercial advertising for soft drinks (for one pertinent and striking example of a Coca-Cola television ad that ran in PNG during the late 1990s, see K. and K. McGrath n.d.; see other examples in Foster 2002 and discussion in Foster in press). In fact, the image of an exotically dressed Native brandishing a soft drink is coeval with the coming of Coca-Cola to PNG. Precisely this image graced the cover of the June 1967 issue of Coca-Cola Overseas, The Coca-Cola Company's in-house magazine for international bottlers, which announced the arrival of a Coca-Cola bottler in the then-UN Trust Territory of Papua and New Guinea. Hega thus made use of a recurrent visual trope-found in travel photography, commercial advertising, and even anthropology textbooks - for making both "culture" and "culture contact" perceptible and intelligible.

Hirsch notes in passing that during one seminar presentation of an account of the calendar competition, participants criticized Alphonse Hega on the grounds that he had allowed himself to be used by the Coca-Cola marketing apparatus and had become complicit in projects of cultural imperialism and global capitalist exploitation (2004: n.18). Yet Hega was explicitly and deeply concerned about cultural imperialism: "Introducing [other] people's culture in our place and not sticking to our own — we will forget our own - our children will think it is ours but it is introduced" (Hirsch 2004:35). Hega flatly rejected a marketing rhetoric that often deployed the native-with-soft drink image to conjure a happy convergence of indigenous and foreign customs in the form of a new generation of Papua New Guineans (see Foster 2002:52). Nevertheless, Hega knew what he needed to do to win the contest and thus further the goal of making public "his culture" on favorable terms. As Hirsch notes: "[Alphonse] can only make use of what he has at his disposal" (2004:36).

Alphonse Hega's photographs illustrate the dynamics of value creation in the economy of qualities as outlined by Callon (and Prahalad and Ramaswamy). His creativity and innovativeness were stimulated by an invitation from the Coca-Cola bottler - an invitation to use a corporate-sponsored calendar contest as a sociotechnical device for making his culture public. Hega seized the opportunity as a chance 
to publicize the autonomy and value of "a culture" - his culture, orphaned by the agents of economic development. But the opportunity was constrained by Hega's effort to articulate a vision of Goilala culture that conformed to his idea of what the Coca-Cola bottling company anticipated. Hega sought to make Goilala culture intelligible in terms that he was confident would be understood. His effort thus clearly fell within the limits and lineage of a managed brand identity; indeed, it stabilized that brand identity. No apparent overflow.

Whether Hega was successful in his project of requalifying Goilala culture by piggybacking on the marketing scheme of a transnational soft drink company is an open question. I have my doubts, however, about its efficacy in assembling the public that Hega had in mind. Hega's reproduction of a "familiar and frequent" image of the modern primitive did not even mobilize Hirsch's university seminar audience. I am uncertain, then, about whom, if anyone besides people reading these words, Hega's picture brought together around his concern about the unjust and inaccurate perception of Goilala culture. I am more confident, however, that the Coca-Cola bottler was satisfied with its own efforts to qualify its products through the agency and creativity of Alphonse Hega - and perforce harness that creativity and agency as a source of surplus value, despite the fact that in this case Hega himself had no emotional investment in branded Coca-Cola products other than a profoundly negative one.

Case 2. Figure 5 stands in not only for an array of attempts to redefine the terms of intelligibility for brand Coca-Cola, but also for a more successful political outcome: the organization of a public around a particular matter of concern, a concern more distributed - that is, impinging on more actors and interests, operating at more and different spatial scales - than Alphonse Hega's concern.

In July 2005, Internet news sites circulated stories about Sharad Haksar, a wellknown commercial photographer based in the city of Chennai (Haskar n.d.; see also Chadha 2005). According to reports, Hindustan Coca-Cola Beverages Private Ltd., a subsidiary of The Coca-Cola Company for whom Haksar had done work in the past, threatened Haksar with legal action on the grounds that he had caused " 'incalculable' damage to the goodwill and reputation of the brand Coca-Cola" (Bhattacharya 2005). At issue was a large billboard that Haksar had placed in a busy area of Chennai. The billboard displayed a photograph of Haksar's that depicted a dry water pump with four empty pots lined up next to it and waiting to be filled. In the background, painted white on a red wall, appear the words "Drink Coca-Cola," the name of the soft drink written in its familiar, distinctive, and trademarked script. 
FIGURE 5. Chennai, India, June 2005: Billboard with controversial picture by Sharad Haksar on busy street. (Picture courtesy of Getty Images/AFP.)

A Coca-Cola spokesperson referred to Haksar's 20 foot by 30 foot billboard as an "infringement of our trademark" (Bhattacharya 2005). The letter sent to Haksar by the law firm representing Hindustan Coca-Cola characterized the billboard as “a deliberate attempt to bring disrepute to my client's global reputation built up by spending millions and millions of rupees and by its quality of product and service" (Bhattacharya 2005). Reputation - the public significance of the Coca-Cola brandwas thus unambiguously claimed as the exclusive creation and property of The Coca-Cola Company, regardless of the logical and material condition of reputation as an interactive or social process, a qualification generated by the ongoing use by consumers of a branded good (see Coombe 1998). From this perspective, Haksar's image was both an attack on and illegal appropriation of the company's capacity to qualify its products. So much for cocreating value.

Haksar defended his billboard as a social message, one in a series of such messages that he had communicated over the previous three years on billboards that occasionally and similarly used trademarked logos (such as the famous Nike swoosh). The social message in this case referred to the scarcity of drinking water in urban Chennai: "I wanted to show the irony of the situation — when there is such acute water shortage, aerated drinks are freely available” (Bhattacharya 2005). Haksar, 
moreover, claimed that the billboard was an expression of his artistic freedom and not an attempt on his part to reap commercial gains: "If MNCs [multinational corporations] do not want their trademark image used in art, they should have a disclaimer on every one of their products! By that yardstick, if I take a photograph of a street, house-owners can object to their house being in the image. Where does it stop?” (Rajagopalan 2005). From this perspective, the legal action threatened against Haksar was an attack on his right and capacity to produce semiotic rather than commercial value, that is, to make meaning or to communicate in the public domain. The question asked by one Mumbai-based blogger commenting on the case is entirely appropriate: "The question is, when a brand and it's [sic] slogan becomes part of the popular culture, how far can it — or should it — be 'protected' " (Bansal 2005).

The disjunction between Haksar and the attorneys' perspectives recalls the extent to which such misalignments in a commodity network are capable of producing unanticipated results. Haksar's own billboard cannot escape this condition. Despite his claim that the point of the billboard was "to highlight the problem of water shortages in my city, and not to bring Coca-Cola down," Haksar's image was perceived differently by activists accusing Coca-Cola bottling plants across India of depleting (or "mining") groundwater, accusations strenuously denied by The Coca-Cola Company (n.d.a). In fact, it was on the website of the India Resource Center (IRC), a cyberspace clearinghouse largely devoted to campaigning against the company's operations in India, that I initially learned of the Chennai billboard controversy. According to an IRC news release that appeared the day after Haksar was served legal notice: "Mr. Haksar's billboard highlights the severe water shortages being experienced by communities that live around Coca-Cola bottling plants across India” (IRC 2005). Amit Srivastava, Coordinator of the IRC, thanked Haksar for the photographer's apparently unintended efforts. That is, Haksar's self-professed gesture of irony had been taken up as a public protest of transnational corporate practice. It was perhaps exactly this interpretation of the Chennai billboard that prompted Hindustan Coca-Cola's legal action in the first place.

Haksar's image and Amit Srivastava's use of it are both unruly overflowings, instances of consumer agency that escaped the bounds of brand management and therefore prompted a call to the trademark — or perhaps Lovemark-police. These overflowings, unlike Alphonse Hega's efforts, both indicate and accomplish the proliferation of concerned groups, that is, the organization of a public around a matter of concern. This public is not coterminous with an already existing social community; it is instead an affiliation of strangers organized by and around the 
consequences of a global corporation's business operations. It is a Deweyan public, consisting of "actors who are jointly implicated in an issue but who do not belong to the same social world; this is why they must get organized into a political community if they are to address the issue in question" (Marres 2005:214). The concerns of the IRC about water tables in India have been linked to the concerns of many trade unionists and student antisweatshop activists over allegations of The Coca-Cola Company's complicity, through its bottlers, in labor violence in Colombia (see Figure 2). These concerns have called into being a public distributed across the planet, a public assembled out of individuals and groups - some of whom might well seem alien to each other-affected in different ways by the externalities of corporate practice. The American Anthropological Association (AAA) and some of its sections have advanced the proliferation of concerned groups by joining this public (AAA 2006).

$$
* * *
$$

The notion of the economy of qualities implies that consumer agency operates, if at all, embedded and distributed within commodity or product networks. What then is the potential for making things public (or making publics around things) to which consumer agency can lay claim, especially given the prevailing views among business consultants and corporate actors that value creation unfolds as joint activity between producers and consumers? And how might making things public redirect or even undo the attempts of firms to define and control this process of value creation?

Both economic sociologists and marketing executives agree that the commodity or product networks characteristic of the current economy of qualities endow consumer agency with an enhanced capacity for value creation. It is this capacity that renders consumer agency of special interest to some firms. On the one hand, consumer agency - in the form, for example, of unique product experiences (cocreated or not) - is a source of the surplus value that firms extract as rent by charging premium prices for the use of their brands. On the other hand, consumer agency is a source of disruption, of unruly overflowings that escape capture and can even destroy value - notably, the value of brands, favorite targets of no logostyle corporate "anti-globalization" activists. This disruption stems from consumer agency's capacity - admittedly uneven and never guaranteed, but surely amplified by new communication technologies - to assemble publics around matters of concern. When these matters of concern originate in the business operations of corporations vending iconic global commodities such as Coca-Cola soft drinks, the proliferation of concerned individuals and groups assembled as a public can seem almost endless. 
Not all attempts to assemble a public will, of course, be successful. Alphonse Hega's efforts to publicize his concerns might well amount to a minor chapter in the conquest of cool (Frank 1997), whereby his creativity was recuperated for the purpose of qualifying a soft drink that he regards as Other rather than as an extension of Self. But there is no reason to accept a grim view of the current economy of qualities as one in which people's labor is inevitably exploited doubly, that is, in both production and consumption. Some attempts at assembling a public will succeed in addressing the matter of concern that brings the public into being. Chances of success increase when economic agents - including consumers - "have the required autonomy to propose new courses of action" (Callon 2005:310). Put differently, success is more likely when concerned individuals or groups threaten to requalify a product in ways that destabilize the fit between a brand and its loyalists. Such has been the outcome of the public - composed in large part of college students on campuses across the United States - that formed around concerns about the less than best practices of Coca-Cola bottlers in Colombia and India.

In 2006, for example, the public mobilized by and around the consequences of The Coca-Cola Company doing business managed to elicit from the company an announcement that the UN International Labor Organization has agreed to conduct an "investigation and evaluation" in Colombia. Critics quickly cast reasonable doubt on the significance of The Coca-Cola Company's concession (see Campaign to Stop Killer Coke n.d.; and Coca-Cola Company n.d.b for more details); and perhaps there is no reason to exaggerate the efficacy of what Callon (2001) calls "hybrid forums"-public spaces in which a wild assortment of differentially competent actors debate the economic, political, legal, ethical, and scientific dimensions of particular markets. Nonetheless, the recent campaign against Coca-Cola exemplifies what Dewey (1946) regarded as the essence of community life; a public has come into being and challenged arbitrary power, acquiring the resources to settle problemsproblems of corporate externalities — otherwise unaddressed by "public officials," whether in India, Colombia, or the United States. In other, modestly optimistic words, the economy of qualities imbues consumer agency with a capacity to perform what Warner (2002) calls "the active uptake" necessary for creating a public and to accomplish thereby greater accountability — and not to consumers and investors only-in the creation of value.

\section{ABSTRACT}

My goal in this article is to apprehend claims about person-product relationships now circulating in the world of business. I take up approaches that presuppose the embeddedness 
of economic action in shifting networks or assemblages of people and things (human and nonhuman actors), and that call attention to the agency distributed within such networks. I discuss the work of Michel Callon and his colleagues and specifically their notion of "the economy of qualities" (Callon et al. 2002). I pose two sets of related questions. First, can we translate marketing claims that relationships between consumers and corporate brands define a locus of value creation into the terms of Marx's theory of value? And how might this translation revise not only the marketing claim, but also Marx's understanding of surplus value creation? Second, can we translate the claim that value creation hinges on a dynamic relationship between corporations and consumers into terms of a theory of participatory democracy? That is, what sort of political potential might inhere in this relationship? In particular, how might this relationship endow consumers with agency not only in value creation but also in "making things public" (Bruno Latour 2005b)? I address these questions of commodity networks and consumer agency with a set of visual props drawn from my research into the sociotechnical lives of an iconic type of global commodity: Coca-Cola brand soft drinks.

Keywords: consumption, value, brands, new economy, Michel Callon, CocaCola

\section{NOTES}

Acknowledgments. This article began as a plenary talk for the 2006 biennial spring conference of the Society for Cultural Anthropology in Milwaukee. I thank Judith Farquhar, with whom I coorganized the conference and developed its theme of "Translations of Value," for her encouragement and support. Three anonymous reviewers provided an unusually rich and provocative set of comments, not all of which I have been able to address, for which I am grateful. Kim Fortun, Dan Reichman, and, especially, Julia Elyachar offered stimulating and detailed responses that have improved the article and given me much to think about besides. Eric Hirsch and Jan Hoeksema generously granted me use of their images. Photographs provided by Yale Daily News and Getty Images are used with permission.

Editor's Note: The "New Economy" and globalization have been analyzed in many Cultural Anthropology articles. See, for example Anna Tsing's "The Global Situation” (2000). Branding and value creation have also been important topics, as, for example in William Mazzarella's award-winning “ 'Very Bombay': Contending with the Global in an Indian Advertising Agency" (2003), and the special issue devoted to value creation introduced by Paul K. Eiss and David Pedersen's, "Introduction: Values of Value" (2002).

\section{REFERENCES CITED}

American Anthropological Association (AAA)

2006 Society for Cultural Anthropology Resolution. Electronic document, http:// www.aaanet.org/sca/meetings/sca/2006/cokeresolution.htm, accessed May 24, 2007. (Reprinted in “Editors' Introduction," p. 617.)

Arvidsson, Adam

2005 Brands: A Critical Perspective. Journal of Consumer Culture 5(2):235-258. 
Bansal, Rashmi

2005 Coca-Cola Sees Red in India. Electronic document, http://www.psfk.com/ 2005 /07/cocacola_sees_r.html, accessed May 24, 2007.

Bhattacharya, Chandrima S.

2005 Cola Behind Empty Pots? Coke Thirsts for a Fight - No Water, No Problem? Telegraph [Calcutta], July 17.

Callon, Michel

1998 An Essay on Framing and Overflowing: Economic Externalities Revisited by Sociology. In The Laws of the Markets. Michel Callon, ed. Pp. 244-269. Malden, MA: Blackwell Publishers.

2001 Economy of Qualities, Researchers in the Wild and the Rise of Technical Democracy. Seminar (11/15/2001), Center for Theoretical Study, the Institute for Advanced Studies at Charles University and the Academy of Sciences of the Czech Republic. Electronic document, http:/www.sfu.ca/ $\sim_{\text {scolr }} /$ PDFREADINGS/callon.htm, accessed March 2, 2006.

2005 Disabled Persons of All Countries, Unite! In Making Things Public: Atmospheres of Democracy. Bruno Latour and Peter Weibel, eds. Pp. 308-313. Cambridge, MA: MIT Press.

Callon, Michel, Cécile Méadel, and Vololona Rabeharosoa

2002 The Economy of Qualities. Economy and Society 31(2):194-217.

Campaign to Stop Killer Coke

N.d. Campaign to Stop Killer Coke. Electronic document, http://www. killercoke.org/, accessed May 24, 2007.

Chadha, Monica

2005 Coke Tries to Can Indian Poster. BBC News, July 17, 2005. Electronic document, http: / / news.bbc.co.uk/2 /hi/south_asia/4690703.stm, accessed May 24, 2007.

Coca-Cola Company

N.d.a The Coca-Cola Company Addresses Allegations Made About Our Business in India. Electronic document, http://www.thecoca-colacompany.com/ presscenter/viewpoints_india_situation.html, accessed May 24, 2007.

N.d.b CokeFacts. Electronic document, http://www.cokefacts.org, accessed May 24, 2007.

Coombe, Rosemary J.

1998 The Cultural Life of Intellectual Properties: Authorship, Appropriation, and the Law. Durham, NC: Duke University Press.

Dewey, John

1946 [1927] The Public and Its Problems: An Essay in Political Inquiry. Chicago: Gateway Books.

Eiss, Paul K., and David Pedersen

2002 Introduction: Values of Value. Cultural Anthropology 17(3):283-290.

Foster, Robert J.

2002 Materializing the Nation: Commodities, Consumption, and Media in Papua New Guinea. Bloomington: Indiana University Press.

2005 Commodity Futures: Labour, Love and Value. Anthropology Today 21(4):8 12.

In press Coca-Globalization: Following Soft Drinks from New York to New Guinea. New York: Palgrave Macmillan.

Frank, Thomas

1997 The Conquest of Cool: Business Culture, Counterculture and the Rise of Hip Consumerism. Chicago: University of Chicago Press.

Granovetter, Mark, and Richard Swedberg, eds.

2001 The Sociology of Economic Life. Boulder, CO: Westview Press. 
Haksar, Sharad

N.d. Sharad Haksar-Photographer. Electronic document, http: / / www.sharadhaksar. com, accessed May 24, 2007.

Hirsch, Eric

1994 Between Mission and Market: Events and Images in a Melanesian Society. Man (n.s.) 29(3):689-711.

1995 Local Persons, Metropolitan Names: Contending Forms of Simultaneity among the Fuyuge, Papua New Guinea. In Nation Making: Emergent Identities in Postcolonial Melanesia. Robert Foster, ed. Pp. 185-206. Ann Arbor: University of Michigan Press.

2004 Techniques of Vision: Disco and Renderings of Present Perceptions in Highland Papua. Journal of the Royal Anthropological Institute (n.s.) 10(1):19-39.

India Resource Center (IRC)

2005 Coca-Cola Threatens Top Indian Photographer with Lawsuit. Electronic document, http:/ /www.indiaresource.org/news/2005/1077.html, accessed May $24,2007$.

Interbrand

N.d. Best Global Brands 2006. Electronic document, http://www.interbrand. com/best_brands_2006.asp, accessed May 24, 2007.

Jones Soda Company

N.d. Home page. Electronic document, http: / / www.jonessoda.com, accessed May 24, 2007.

K. and K. McGrath

N.d. Kevin McGrath-Producer. Electronic document, http://www.mcgrath.net/ MPG/COKE_papua_small.MOV, accessed May 24, 2007.

Latour, Bruno

2005 a Reassembling the Social: An Introduction to Actor-Network-Theory. Oxford: Oxford University Press.

2005 b From Realpolitik to Dingpolitik: Or How to Make Things Public. In Making Things Public: Atmospheres of Democracy. Bruno Latour and Peter Weibel, eds. Pp. 14 41. Cambridge, MA: MIT Press.

Lippmann, Walter

1925 The Phantom Public. New York: Harcourt, Brace.

Lovemarks.com

N.d. Lovemarks: The Future Beyond Brands. Electronic document, http:// www.lovemarks.com/, accessed May 24, 2007.

Marx, Karl

1967 [1867] Capital, Volume 1. Samuel Moore and Edward Aveling, trans. New York: International Publishers.

Mazzarella, William

2003 "Very Bombay": Contending with the Global in an Indian Advertising Agency. Cultural Anthropology 18(1):33-71.

Marres, Noortje

2005 Issues Spark a Public Into Being: A Key but Often Forgotten Point of the Lippmann-Dewey Debate. In Making Things Public: Atmospheres of Democracy. Bruno Latour and Peter Weibel, eds. Pp. 208-217. Cambridge, MA: MIT Press.

Miller, Daniel

1987 Material Culture and Mass Consumption. New York: Basil Blackwell.

Munn, Nancy D.

1983 Gawan Kula: Spatiotemporal Control and the Symbolism of Influence. In The Kula:

New Perspectives on Massim Exchange. Jerry W. Leach and Edmund Leach, eds. Pp. 277-308. Cambridge: Cambridge University Press. 
O'Shaughnessy, John, and Nicholas Jackson O'Shaughnessy

2003 The Marketing Power of Emotion. New York: Oxford University Press.

Prahalad, C. K., and Venkat Ramaswamy

2000 Co-Opting Customer Competence. Harvard Business Review 78(1):79-87.

2004a Co-Creation Experiences: The Next Practice in Value Creation. Journal of Interactive Marketing 18(3):5-14.

2004 b The Future of Competition: Co-Creating Unique Value with Customers. Boston: Harvard Business School Press.

Ponte, Stefano, and Peter Gibbon

2005 Quality Standards, Conventions and the Governance of Value Chains. Economy and Society 34(1):1-31.

Rajagopalan, Sudha

2005 A Soft Drink Giant, a Photographer, and Artistic License. The Power of Culture, August 2005. Electronic document, http://www.powerofculture. nl/uk/current/2005/august/haksar.html, accessed May 24, 2007.

Roberts, Kevin

2004 Lovemarks: The Future Beyond Brands. New York: Powerhouse.

Slater, Don

2002 Markets, Materiality and the "New Economy." In Market Relations and the Competitive Process. Stan Metcalfe and Alan Warde, eds. Pp. 95-113. New York: Manchester University Press.

Taylor, William C.

2006 To Charge Up Customers, Put Customers in Charge. New York Times, June 18. Electronic document, http://www.nytimes.com/2006/06/18/business/your money $/ 18 \mathrm{mgmt} . \mathrm{html} ? \mathrm{ex}=1186113600 \& \mathrm{en}=97 \mathrm{be} 51 \mathrm{~b} 5 \mathrm{a} 5 \mathrm{c} 709 \mathrm{c} 2 \& \mathrm{ei}=5070$, accessed July 31, 2007.

Trendwatching.com

N.d. Consumer Trends and Insights from Around the World. Electronic document, http://www.trendwatching.com/trends/CUSTOMER-MADE.htm, accessed May 24, 2007.

Tsing, Anna

2000 The Global Situation. Cultural Anthropology 15(3):327-360.

Warner, Michael

2002 Publics and Counterpublics. Public Culture 14(1):49-90. 